\title{
Building Family Resilience Through Phylantrophy and Populist Policies to Cope The Covid-19 Pandemic in Indonesia
}

\author{
Sjafiatul Mardliyah ${ }^{1}, *$ Putri Aisyiyah Rachma Dewi ${ }^{2}$, Awang Dharmawan ${ }^{2}$, \\ Agus Prasetyawan $^{3}$, Yuni Lestari ${ }^{3}$
}

\author{
${ }^{I}$ Non Formal Education Department Universitas Negeri Surabaya, Indonesia \\ ${ }^{2}$ Communication Science Department Universitas Negeri Surabaya, Indonesia \\ ${ }^{3}$ Public Administration of vocational programme Universitas Negeri Surabaya, Indonesia \\ ${ }^{*}$ Corresponding author. Email: sjafiatulmardliyah@unesa.co.id
}

\begin{abstract}
Family resilience is an essential factor to cope with the Covid-19 pandemic. This study aims to identify various efforts, from the state to the family, as the smallest unit in society, to build their strength during the crisis. This research was carried out through two methods, survey, and discourse analysis. The results explain that building family resilience during the pandemic can be realized only when relationships as social capital are developed by the society and the state in the cultural and structural dimensions. The cultural dimension is characterized by the emergence of institutionalized social philantropyh. This perspective is reflected by religious and social philanthropy, as well as personal and communal philanthropy. Meanwhile, the structural dimension is reflected by populist policies were issued by local, provincial, and central government policies.
\end{abstract}

Keywords: philanthropy, populist policies, social capital, family resilience, covid-19

\section{INTRODUCTION}

Since WHO declared Coronavirus Disease (Covid19), which emerged firstly in Wuhan-China, as a global pandemic at the end of 2019, in April 2020 the virus infection has reached $1,942,360$ people in 185 countries. "Pandemic" status causes global consternation because there has not been found an elixir nor the vaccine. Families should be care of health and economic issue at the same time, mainly for middle-low categories. As seen in the government report, one of the worst regions in the covid-19 issue is East Java Province. The province got a "red zone" label. It shows that the government failed to handle the situation and the graphic of infection increases day by day.

Figure 1 shows that the City of Surabaya, Sidoarjo Regency, and Gresik Regency are the three regions with the highest number of people who are infected by the viruses in East Java. Meanwhile, citing the opinion of the minister of finance, that during the pandemic poor and vulnerable families in the informal sector lost their income because they were unable to work and meet their primary needs [1].

The public sector that has also been affected by the pandemic is education. Data shows that there are still $11.87 \%$

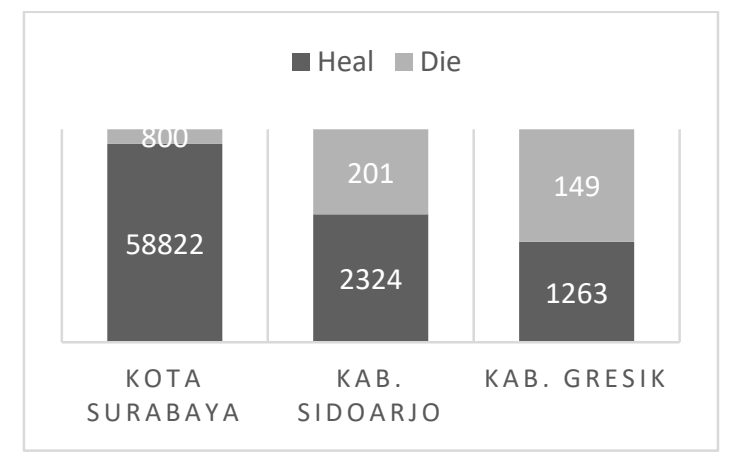

Figure 1. The highest spread of covid-19 in East Java Province (source: official Instagram @jatimpemprov) 
(2019) of households with school-age children (7-18 years old) not attending school. The public sector that has also been affected by the pandemic is education. Data shows that there are still $11.87 \%$ (2019) of households with school-age children (7-18 years old) not attending school. While those who attend school have not been able to go to school normally since the pandemic emerged. Meanwhile, more than 50 million students and college students in Indonesia cannot fully rely on technology during online learning because not all students have computers and internet access. The decrease in family income results in a decrease in the family's ability to finance education. If the pandemic lasts a long time, it can reduce students' motivation to return to school [2].

The pandemic situation encourages people to make adaptations for survival. The following research results discuss various forms of community, family, and household resilience that have different social, economic, and cultural situations facing the current pandemic.

An element that is also interesting to study related to disaster conditions is the result of research on philanthropy. Philanthropy and support of female volunteers maintain the political culture, participation in institutional development, and social reform [3]. There are at least two forms of philanthropy that develop in society, namely religious philanthropy and social philanthropy [4]. Religious philanthropy is the generosity of religious traditions in Indonesia which have different terms or concepts even though in essence there is a common goal to help fellow human beings [5]. The universality of the concept of philanthropy cannot be denied having an impact on philanthropic practices in society. This means that the broad involvement of all human activities in various fields with full willingness, participation, dedication, ideas, free time, material contributions is an inseparable part of the conception of philanthropy.

The results of the research above describe the form of community behavior to maintain family resilience during the pandemic. However, the increasing number of unemployed is a worrying fact and affects social vulnerabilities that can threaten family resilience. This condition certainly affects people to carry out social activities called philanthropy as behavior that appears to deal with crises. Meanwhile, the state certainly does not remain silent and comes up with various populist policy schemes together with the community against the economic crisis due to the pandemic. It's just that the dimension between society and the state in developing social behavior as a collective asset to build family resilience during the pandemic has not been studied further. Based on these reasons, this study aims to identify various community and state efforts that affect realizing family resilience in facing the crisis.

\section{METHOD}

The research in this scheme consists of two separate methods, namely the survey method and the content analysis method. The survey method was conducted to obtain quantitative data on philanthropy in the communities living in Surabaya, Sidoarjo, and Gresik as red zone areas which include independent and communal philanthropy, and the efforts made by the community during the pandemic period [6]. While the content analysis method is used to identify a map of the distribution of information in the form of religious philanthropy and social philanthropy carried out by social organizations and populist policies starting at the City/Regency Government level, Provincial Government, and central policies towards handling Covid-19 [7]

\section{RESULTS AND DISCUSSIONS}

Scalar The findings of the data distributed online in three red-zone locations, namely: Surabaya, Gresik, and Sidoarjo describe the distribution of respondents, gender, age, last education, philanthropic efforts, both personal and communal when facing a pandemic. Questionnaires, which were randomly distributed through google forms in three red-zone locations, returned with a total of 308 respondents.

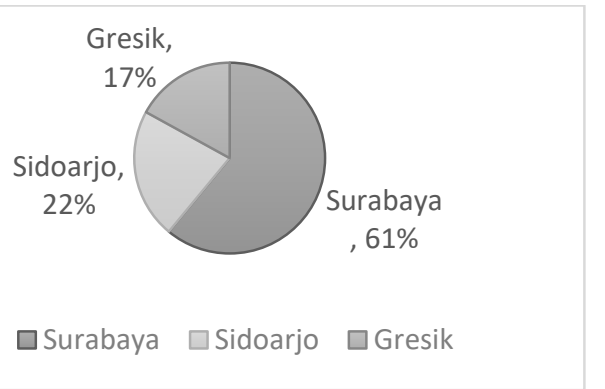

Figure 2. The domicile of respondents

Figure 2 explains that out of 308 respondents, 189 respondents $(61 \%)$ live in Surabaya. Furthermore, respondents from Sidoarjo with a total of 67 respondents $(22 \%)$. Then 52 people (17\%) live in Gresik. The uneven distribution is caused by several factors such as signaling and information disclosure.

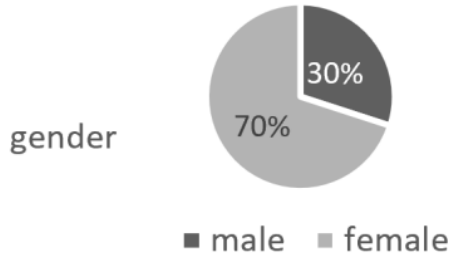

Figure 3. Distribution of respondents in the three red zone areas by gender. 
This shows that female respondents are more concerned about facing the pandemic situation compared to male respondents.

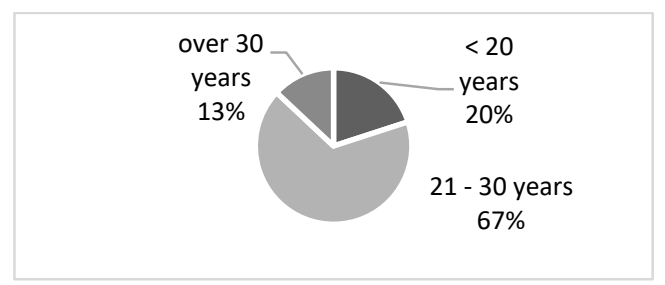

Figure 4. Characteristics of respondent's age

Figure 4 explains that the age characteristics of respondents, aged under 20 years were 61 people (19.8\%), while those aged 21 to 30 years reached 205 people $(66.6 \%)$ and respondents aged 30 years and overreached 42 people (13.6\%). This data explains that respondents of productive age have a good understanding of dealing with the pandemic situation. In general, they are a group of households that have not yet established socio-economic conditions, both due to domestic and public factors.

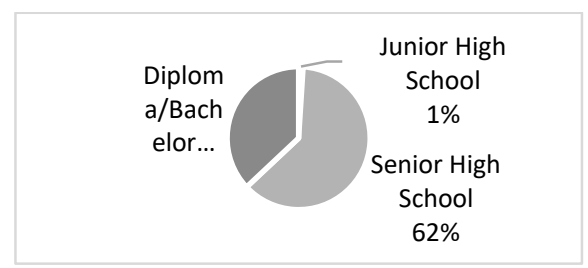

Figure 5. Education background of respondents

Figure 5 explains that the majority of respondents have the last education of high school, vocational or equivalent with a total of 190 people $(61.7 \%)$. Then respondents with the last education equivalent to diploma and bachelor's degree with a total of 114 people (37\%). And the remaining 1.3 percent are respondents who have a low level of education. Furthermore, the following table describes the forms of philanthropy, both personal and communal, that are carried out by people in the red zone during the pandemic period, described in Figure 6.

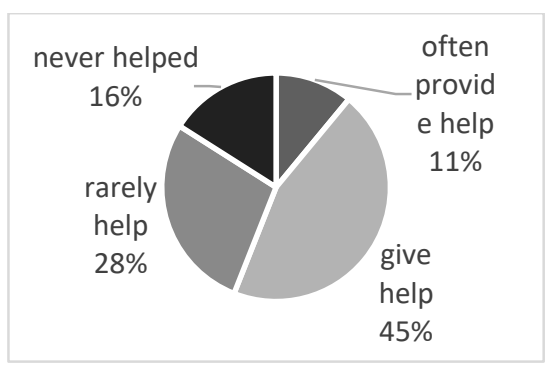

Figure 6. The pattern of personal philantrophy

Figure 6 explains that of the 308 household respondents in the red zone area, 51 households (16.5\%) have not assisted the pandemic, while 87 households $(28.2 \%)$ rarely assist. Meanwhile, a total of 137 households $(44.5 \%)$ of families have provided independent assistance in the form of necessities, money, medicines to their families, neighbors, and friends during the pandemic. Meanwhile, as many as 31 households $(10.8 \%)$ often provide independent assistance. Thus, $55.3 \%$ of families in the red zone have made independent philanthropic efforts to provide social assistance for other community members to maintain family resilience during this pandemic. In addition to independent philanthropy efforts, communal philanthropic efforts are also carried out by households belonging to other social groups such as recitation, social gathering, and other social groups. The table below describes the distribution of households that have provided communal assistance during the pandemic.

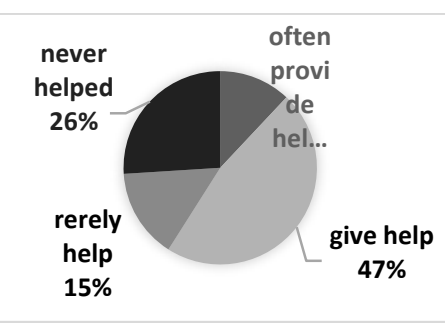

Figure 7. Communal philanthropy in the three red zone areas of East Java

Figure 7 describes the efforts made by 308 households in the three red zone areas to assist by working together through the social groups they participate in. A total of 47 households $(15.2 \%)$ have not assisted, while 81 households (26.3\%) rarely assist. There are 143 households (46.4\%) who have assisted by working together through recitation groups, social gatherings, and hobbies. The assistance provided in addition to basic necessities is hand sanitizer, masks, and disinfectant equipment. Meanwhile, 37 households $(12.1 \%)$ often provide mutual assistance to other families in need. So that there are 180 households $(58.5 \%)$ of households that carry out communal philanthropy to help family resilience due to the pandemic.

Philanthropic efforts are also carried out by social institutions and other educational institutions such as LAZISNU, Lazismu, BAZNAS, UCC Unesa. Data compiled from the official website states that LAZISNU distributed funds amounting to eighty-four point nine billion rupiahs during the fasting month to people in East Java. For the Sidoarjo area, the funds given to the community amounted to Rp. 22 billion which was distributed to 89,751 mustahik (who are entitled to receive) [8]. In April, LAZIZNU has distributed 1000 PPE to dozens of hospitals [9]. LAZIZNU also eased the burden on several families who were positive for Covid19 in the Gresik area to be able to undergo the quarantine period in peace [10]. Meanwhile, information compiled from the official website managed by Lazismu East Java explained that the number of donations collected until August 2020 to deal with COVID-19 was Rp. 691,945,000.00. Of the total funds collected, Lazismu distributed assistance in the form of: PPE, masks, 
disinfectants, hand sanitizers, nutrition \& vitamins to residents affected by Covid-19. Coinciding with the moment of the Qur'ban celebration, this institution also created a program for slaughtering Qurban animals to be distributed to people in need to achieve food security [11]. The corona pandemic that hit the people's economy, made BAZNAS East Java also try to help households who rely on the informal sector for their livelihood. Several MSME actors receive business capital assistance so that they can survive during the pandemic [12].

On the other hand, the role of higher education institutions is not left behind to help the community face the pandemic. As done by the State University of Surabaya, specifically educating UCC (Unesa Crisis Center) which aims to prevent the spread of Covid-19 in East Java. The form of assistance provided is in the form of research and community service programs specifically taken from Unesa's internal funds. Various outputs from research activities and community service in the form of masks, hand sanitizer, PPE, food packages, robots, antihoax websites, various processed traditional plants are distributed in various areas in East Java. In addition, there is a KKN program that aims to assist families facing the pandemic with various activities such as study assistance, spraying, distribution of necessities, assistance to microbusiness units [13]

Populist policies are leadership policies at the regional and central levels, which are chosen as a form of taking sides with the community without requiring the support of political parties (Haboddin, 2019). During this pandemic, populist policies have been issued by city/district leaders. The COVID-19 handling policy in Surabaya can be seen from the issuance of Mayor Regulation. Similar steps were also taken by the Regency Government Sidoarjo by issuing Sidoarjo Regent Regulation No. 31 of 2020 concerning Guidelines for the Implementation of Large-Scale Social Restrictions in Handling the 2019 Corona Virus Disease Outbreak in Sidoarjo Regency. At the provincial government level, there are two governors and two governors that have been issued to reduce the impact of COVID-19 by issuing a governor's regulation. Clarity of information and transparency are the main principles so as not to cause social problems in the community. Populist policies in the form of cash social assistance and necessities significantly sided with family resilience from an economic point of view.

Various populist policies implemented by the regional and central governments have also received public responses. The results of a survey on people living in the red zone show the level of trust of respondents in government social assistance for people affected by Covid19 as an effort to support family resilience, which can be explained in Figure 8

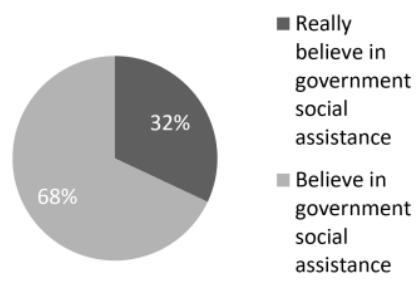

Figure 8 Level of Trust in Government Assistance for Communities Affected by Covid19

Figure 8 explains that as many as 121 respondents $(39.3 \%)$ believe that the social assistance provided by the government to communities affected by Covid19 can support family resilience. Meanwhile, 58 respondents $(18.8 \%)$ strongly believe that the social assistance provided by the government supports family resilience. So it can be concluded that the community believes that the social assistance provided by the government to people affected by COVID-19 supports family resilience during the pandemic. Meanwhile, all respondents agreed to place the government as the institution most responsible for providing services to the community due to the Covid-19 pandemic. Populist policies in the form of lockdown policies and various social assistance policy schemes have attracted public sympathy during the pandemic. Populist policies issued by City/Regency Governments, Provincial Governments, and Central Governments have been derived into concrete steps through programs that grow and develop family resilience in the face of pandemic disasters. Efforts to build family resilience during a pandemic can be schematically described as Figure 9

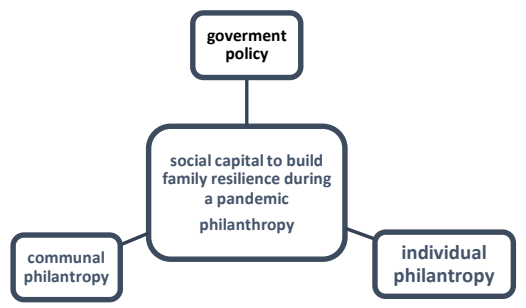

Figure 9. Strategies for building social capital to build family resilience in times of pandemic

Figure 9 explains that the social relationship between philanthropy and state policy is the basis of social, economic, cultural, and political power to build family resilience during a pandemic. Payton and Moody explain that voluntary action for the public good is a voluntary act based on public needs [14]. The process of rehabilitation and reconstruction during the pandemic and post-pandemic period requires a long time, large funds, and resources in various fields to build the recovery of various sectors of life due to Covid-19. This condition demands the importance of building social capital to support activities that utilize trust, values, and norms as well as social networks to encourage the participation of the community, government, nongovernmental organizations, business actors, and 
professionals in an effort to create socio-economic conditions like before the pandemic [15]. Efforts to realize family resilience in the face of a pandemic require quite complex rationality, arguments, and principles. The degree of acceptance, ability to capture, and the response of citizens to rationality, argumentation, and principles is quite diverse. Some members of the community can accept, can capture, and give a positive response, but some other people feel that they do not need to follow it. For people who give a positive response to the pandemic conditions, it gives birth to social philanthropic behavior both independently and in groups. This reasoning is in line with Samuda's opinion that social networks that grew based on awareness of positive norms have worked at the individual and community levels into social capital to build disaster-resilient families [16].

The discussion of social capital at the individual level is colored by descriptions that emphasize that each actor accesses and utilizes the resources that are deposited in the network to obtain optimal economic and social benefits. Meanwhile, diversity in receiving, capturing, and responding is also facilitated by local organizations to increase the required participation and social networks. The presence of social institutions such as Lazisnu, Lazismu, Bazis as well as educational institutions has a significant contribution through targeted, effective, and efficient actions involving community members, government, and private parties. This condition is a form of social relations developed by the community in the process of developing knowledge, awareness, and attitudes about the negative impacts of disasters, as well as the community's process of rebuilding their lives.

Society has developed social capital and fulfills three characteristics, namely bonding social capital, bridging social capital, and linking social capital [17]. Bonding social capital is characterized by bonds or connections that institutionalize emotional closeness in the form of kinship, friendship, and neighborhood. People living in Surabaya, Gresik, and Sidoarjo as pandemic red zone areas, have the same geographic, knowledge, values, and social norms, the same information when facing the Covid-19 pandemic. Independent philanthropy and mutual assistance to the community in this region have emotional ties and obligations to strengthen each other when facing a pandemic.

The characteristics of these bonds are different from the characteristics of the bonds attached to bridging social capital. Social networks in bridging social capital are more open. Social relations that grow and develop in it are connected or bridged (bridging) by certain groups or organizations. The presence of social institutions such as Lazisnu, Lazismu, Bazis, and educational institutions play a role in bridging various interests and disseminating information needed to identify problems and alternative solutions, meet basic needs, and take advantage and create opportunities. The existence of such groups or organizations creates conditions conducive to building trust, integration, and interdependence. This social institution institutionalizes togetherness and strengthens each other when facing Covid-19.

On the other hand, ties or connections are different from those that are embedded in bridging social capital, because they put pressure on the social relations that exist between citizens (citizens) and official institutions that are part of the government system. Various populist policy schemes starting at the district/city, provincial, central government levels have been institutionalized as a consequence and response from the government for the pragmatic and partial public interest [18]. Such conditions indicate that democratic leadership is needed in managing social capital in dealing with disasters [19]. But on the other hand, it also provides opportunities for the emergence of new compromises that mark the formation of a new policy context that adds dynamics to the implementation of other populist policies [20].

Furthermore, according to LaLone, as quoted by Usman, there are factors of social capital resources that influence the mobilization of social capital, namely social organizations that voluntarily provide services for the needs of disaster victims, both material and non-material. Social and social organizations are based on humanity and prioritize relationships that are framed by trust, are selfless, and avoid calculating profit and loss. The relationship between social organizations and the community in linking ties involves many outside parties and is complex compared to bonding and bridging social organizations [21].

Meanwhile, the role of the state represents a structural dimension that supports the birth of populist policies, is interdependence between the state and society as a response and a stimulant that adapts to changes in the social environment during the pandemic. Following Bourdieu's opinion, the populist policy is an established and legitimate domination habitus that makes people pay attention to structured and authoritative power structures [22]. The government has issued three strategic policies during the pandemic, namely the allocation policy, distribution policy, and stabilization policy as a systematic policy in dealing with the economic impact of the Covid-19 pandemic that occurred in Indonesia [23]. Following Portes' opinion, that the relationship between philanthropy and populist policies as social capital to build family resilience during a pandemic, stems from consummatory and instrumental patterns. Social capital is categorized as sourced from consummatory patterns when the social solidarity that is in it is not formed from birth, but values that grow and develop based on the struggle for common goals or interests. While the sources of social capital in the instrumental pattern are developed through mutually reinforcing exchanges (reciprocity exchange). The assumption is that social life is an interdependent entity [24]. The limitation of this research 
is that it is not possible to conduct direct interviews given the impossible conditions. Data collection, which was conducted online through the Google Form platform, could not describe in more detail the social and cultural aspects directly.

\section{CONCLUSION}

The conclusion of this paper confirms that philanthropy and populist policies give birth to meaningful social capital to create family resilience in the face of a pandemic. Social capital has a contribution to disaster preparedness (preparedness), emergency or disaster response (response), and recovery (recovery) activities in handling the Covid-19 pandemic disaster problem. Social capital is the social relations developed by the community and the state in the process of developing knowledge, awareness, and attitudes about the negative impacts of disasters, as well as the community's process of rebuilding their lives and livelihoods after a pandemic disaster occurs.

This paper suggests that populist policies need to synergize with philanthropy effectively and efficiently as social capital to strengthen family resilience. The state should be present as a facilitator to strengthen relations by expanding the social and economic power network of the multicultural Indonesian people. It is at this point that structural and social agent relations meet to create family resilience.

\section{REFERENCES}

[1] P. A. Antara dan S. A. Candra, "Empat Sektor Ekonomi yang Paling Tertekan Pandemi Covid-19," 07 Agustus 2020. [Online]. Available: Republika.co.id: https://republika.co.id/berita/q831lp409/empat-sektorekonomi-yang-paling-tertekan-pandemi-covid19. [Diakses 20 November 2021].

[2] S. H. Harmadi, "Ketahanan Keluarga di Masa Pandemi," 29 Juni 2020. [Online]. Available: https://mediaindonesia.com/read/detail/323946-ketahanankeluarga-di-masa-pandemi. [Diakses 20 November 2021].

[3] R. Rinawati, "Pemberdayaan Perempuan dalam Tidaya Pembangunan melalui Pendekatan Komunikasi Antarpribadi," dalam SNaPP: Sosial, Ekonomi, dan Humaniora, Bandung, 2017.

[4] I. H. Tamim, "Filantropi dan Pemnagunan," Jurnal Community, vol. 1, no. 1, pp. 124-137, 2016.

[5] A. A. Widianto, "Aktivisme, Filantropi Sosial dan Pemberdayaan Perempuan di Yogyakarta: Studi terhadap Dinamika Aktivisme Yayasan Sahabat Ibu dalam Pemberdayaan Perempuan di Yogyakarta.," Jurnal Sosiologi Reflektif, vol. 12, no. 2, pp. 193-212, 2018.

[6] M. Singarimbun dan S. Effendi, Metode Penelitian Survai, Jakarta: LP3ES, 2006.

[7] Eriyanto, Analisis Wacana: Pengantar Analisis Teks Media., Yogyakarta: LKiS, 2011.

[8] A. W. Permani, "LAZISNU se-Jatim Salurkan Dana 84,9 Miliar Selama Ramadan," 07 Juni 2020. [Online]. Available:

https://www.suarasurabaya.net/kelanakota/2020/lazisnu-se- jatim-salurkan-dana-rp849-miliar-selama-ramadan/. [Diakses 20 November 2021].

[9] A. W. Permani, "LAZISNU JAtim Salurkan 1000 APD ke Puluhan Rumah Sakit.," 25 Agustus 2020. [Online]. Available:

https://www.suarasurabaya.net/kelanakota/2020/lazisnujatim-salurkan-1000-apd-ke-puluhan-rumah-sakit/. [Diakses 21 November 2021].

[10] A. R. Ahdori, "NU Care Ranting Banyutengah Gresik Salurkan Bantuan bagi Keluarga Positif Covid-19," 25 Agustus 2020. [Online]. Available: https://nucare.id/news/keluarga_positif_covid_19_di_gresi k_dapat_bantuan_nu_care_lazisnu. [Diakses 20 November 2021].

[11] "Lazismu Jawa Timur," 22 Agustus 2020. [Online]. Available: http://www.lazismujatim.org/?s=covid. [Diakses 20 November 2021].

[12] “BAZNAS Jawa Timur," 25 Agustus 2020. [Online]. Available: https://baznasjatim.or.id/penjual-nasi-kotakterdampak-corona-bersyukur-dibantu-baznas-jatim/. [Diakses 20 November 2021].

[13] "Unesa Crisis Center (UCC)," 26 Agustus 2020. [Online]. Available: https://www.unesa.ac.id/unesa-bentuk-unesacrisis-center-ucc-untuk-cegah-penyebaran-covid-19. [Diakses 20 November 2021].

[14] Payton dan Moody, Understanding Philanthropy: It is Meaning and Mission, Indianapolis: Indiana University Press., 2008.

[15] S. Usman, Modal Sosial, Yogyakarta: Pustaka Belajar, 2018.

[16] S. Samuda, "Bari Fola sebagai Modal Sosial dan Instrumentasi Masyarakat Tangguh Bencana.," Penelitian Humaniora, vol. 21, no. 2, pp. 109-118, 2016.

[17] D. Aldrich dan M. Meyer, "Social Capital and Community Resilience. American Behavioral Scientist," American Behavioral Scientist, pp. 254-269, 2014.

[18] C. Mudde dan C. Kaltwasser, Populism: A very short introduction., 2017.

[19] T. Yuniarti, "Kepemimpinan dan pengelolaan modal sosial dalam penanggulangan bencana banjir," [1] Yuniarti, T. (2018). Kepemimpinan dan pengelolaan modalMakna: Jurnal Kajian Komunikasi, Bahasa, dan Budaya, vol. 3, no. 1, pp. 94-128, 2018

[20] M. Grindle, Politics and policy implementation in the third word, New Jersey: Princeton., 2017.

[21] S. Usman, Modal Sosial, Yogyakarta: Pustaka Pelajar, 2018.

[22] R. Harker, C. Mahar dan C. Wilkes, [9] Harker, R., Praktik (Pengantar Paling Komprehensif kepada Pemikiran Pierre Bourdieu) (terj), Yogyakarta: Jalasutra, 2009.

[23] H. Kurniawansyah, A. Amrullah, M. Salahuddin, M. Muslim dan S. Nurhidayati, "[11] Kurniawansyah, H., Amrullah, A., Salahuddin, M., Muslim, M., \& Nurhidayati, S. (2020). Konsep Kebijakan Strategis Dalam Menangani Eksternalitas Ekonomi dari Covid-19 Pada Masyarakat Rentan di Indonesia.," Indonesian Journal of Social Sciences and Humanities, vol. 1, no. 2, pp. 130-139, 2020.

[24] A. Portes, "Social Capital: Its Origin and Application in Modern Sociology," Annual Review of Sociology 22, 1-24., vol. 22, pp. 1-24, 1998 . 